\title{
O Estado burguês e a prisão: algumas considerações sobre a funcionalidade do aprisionamento no sistema capitalista*
}

\author{
The bourgeois state and prison: some considerations about the functionality of the \\ imprisonment in the capitalist system
}

\author{
Dione Lolis ** \\ Leonardo Moraes da Silva ${ }^{* * *}$
}

\begin{abstract}
Resumo:
Este artigo tem por objetivo analisar a funcionalidade da prisão no sistema capitalista de produção. Faz uma discussão teórica, fundamentada em autores que analisam a essência do Estado e da prisão, do Estado burguês e do aprisionamento no capitalismo. Parte da concepção de que a prisão configura-se como um dos elementos materiais que constituem a força do Estado burguês e, consequentemente, possui um papel fundamental na dominação e exploração de classe. Constata que, assim como o próprio Estado burguês, as funções da prisão são determinadas de acordo com os estágios do desenvolvimento capitalista, evidenciando o fato de que tal instituição apresenta-se como um importante instrumento estatal no âmbito da regulação da força de trabalho, sobretudo no terreno em que Marx denominou de superpopulação relativa.
\end{abstract}

Palavras-Chave: Estado. Prisão. Capitalismo. Superpopulação relativa. Força de trabalho.

\begin{abstract}
:
This article aims to analyze the functionality of prison in the capitalist system of production. It makes a theoretical discussion, based on authors who analyze the essence of the state and prison, the bourgeois state and the imprisonment in capitalism. Part of the conception that prison is one of the material elements that constitute the force of the bourgeois state and, consequently, plays a fundamental role in class domination and exploitation. It notes that, like the bourgeois state itself, the functions of imprisonment are determined according to the stages of capitalist development, evidencing the fact that this institution presents itself as an important state instrument in the sphere of labor force regulation, especially in the terrain on which Marx called relative overpopulation.
\end{abstract}

Keywords: State. Prison. Capitalism. Relative overpopulation. Workforce.

\section{Introdução}

A intervenção do Estado através do aprisionamento vem intensificando-se progressivamente nas últimas décadas em diversos países; consequentemente, este fato reafirma a prisão como um instrumento fundamental à ordem capitalista . Não obstante,

\footnotetext{
* Esta pesquisa recebeu o apoio da Coordenação de Aperfeiçoamento de Pessoal de Nível Superior (CAPES).

${ }^{* *}$ Assistente Social. Mestre em Serviço Social (PUC/SP). Doutora em Sociologia (Unesp/FCLAR). Docente do Curso de Serviço Social Universidade Estadual de Londrina. E-mail: dionelolis@uol.com.br

${ }^{* * *}$ Assistente Social. Mestre em Serviço Social e Política Social pela Universidade Estadual de Londrina - UEL. Email: leonardomoraes.as@gmail.com
} 
é possível constatar que, desde a acumulação primitiva do capital, o encarceramento exercido pelo Estado sempre assumiu um caráter extremamente funcional à consolidação e legitimação do capitalismo.

Diversas análises referentes ao sistema prisional brasileiro têm ignorado o caráter de classes do Estado. Em consequência, apropriam-se da prisão desvinculando-a da luta de classes e da economia política. Esse tipo de abordagem reformista - e algumas abolicionistas - termina por atribuir à prisão funções incompatíveis à sua natureza na mecânica do modo produção capitalista.

Para compreender em sua totalidade qualquer temática referente ao aprisionamento, faz-se necessário, partir da concepção marxista de que a prisão se constitui como um elemento material do Estado. Com base nessa perspectiva, é possível perceber que, ao longo do desenvolvimento do capitalismo, as funções da prisão são condicionadas de acordo com as mutações capitalistas imputadas ao Estado. Ou seja, em momentos de "progresso" capitalista, a principal intervenção do Estado na reprodução e manutenção da força de trabalho - sobretudo, no âmbito da superpopulação relativa - se dá através de políticas no âmbito social. Por outro lado, em períodos de crises capitalistas, o mesmo Estado burguês aprofunda a sua intervenção por meio do aprisionamento.

Nesse sentido, este artigo tem como objetivo analisar a funcionalidade da prisão no sistema capitalista de produção. Para tanto, desenvolve uma discussão teórica, fundamentada em autores que analisam a essência do Estado e da prisão, do Estado burguês e do aprisionamento no capitalismo.

Parte do pressuposto de que o aprisionamento constitui-se como um aparelho classista essencial à regulação da força de trabalho, mais precisamente, como uma das vias na qual o Estado intervém no âmbito da superpopulação relativa.

\section{A Essência do Estado e da Prisão}

Antes de compreender a natureza da prisão e sua funcionalidade no sistema capitalista, torna-se indispensável examinar a origem do próprio Estado. Este configura-se como fruto da sociedade em um determinado momento, consequentemente, não existiu sempre. Houve sociedades que passaram sem ele e não desenvolveram nenhum tipo de poder governamental. Nesse sentido, 
O Estado não é, pois, de modo algum, um poder que se impôs à sociedade de fora para dentro. Tampouco é a 'realidade da ideia moral' nem 'a imagem e a realidade da razão', como afirma Hegel. É, antes, um produto da sociedade, quando esta chega a um determinado grau de desenvolvimento. É a confissão de que essa sociedade se enredou numa irremediável contradição com ela própria e está dividida por antagonismos irreconciliáveis que não consegue conjurar. Mas para que esses antagonismos, essas classes com interesses econômicos colidentes não se devorem e não consumam a sociedade numa luta estéril, faz-se necessário um poder colocado aparentemente por cima da sociedade, chamado a amortecer o choque e mantê-la dentro dos limites da 'ordem'. Esse poder, nascido da sociedade, mas posto acima dela e que dela se distancia cada vez mais, é o Estado (ENGELS, 2014, p. 208).

O autor demonstra claramente a significação do Estado e a sua função histórica na sociedade, ou seja, que essa instituição é o efeito e a expressão da luta inconciliável das classes. O Estado surge para atenuar o antagonismo existente entre as classes, e, nessa perspectiva, ele não poderia surgir e nem desenvolver-se caso a conciliação das classes fosse possível.

É importante destacar, entretanto, que "o poder do Estado não paira no ar" (MARX, 2011, p.142). Muito pelo contrário, “o Estado é um órgão de dominação de classe, um órgão de submissão de uma classe por outra; é a criação de uma ordem que legalize e consolide essa submissão, amortecendo a colisão das classes" (LENIN, 2010, p. 27). Nessa perspectiva, o Estado não é uma instituição neutra, isto é, ele não nasceu e nem se desenvolve livre das determinações da classe social dominante, muito menos responderá a interesses antagônicos. Friedrich Engels (2014, p. 211) destaca que:

Como o Estado nasceu da necessidade de conter os antagonismos das classes, e como, ao mesmo tempo nasceu em meio ao conflito delas, é, por regra geral, o Estado da classe mais poderosa, da classe economicamente dominante, classe que, por intermédio dele, se converte também em classe politicamente dominante e adquire novos meios para a repressão e exploração da classe oprimida.

A partir de tal compreensão, torna-se necessário ressaltar o fato de que o Estado é determinado de acordo com o modo de produção, assumindo o papel de um instrumento de uma determinada classe, ou seja, da classe dominante.

A sociedade, que se movera até então entre antagonismos de classe, precisou do Estado, ou seja, de uma organização da classe exploradora correspondente para manter as condições externas de produção e, portanto, particularmente, para manter pela força a classe explorada nas condições de opressão (a escravidão, a servidão ou a vassalagem e o trabalho assalariado), determinadas pelo modo de produção existente (ENGELS, 2011, p. 92). 
Ao dar continuidade aos estudos sobre a origem do Estado, Engels desenvolve a noção de que um dos aspectos que compõem essa máquina é a instituição de uma força. Força esta proveniente da sociedade, mas superior a ela e que dela se afasta cada vez mais (LENIN, 2010). Nesse sentido,

\begin{abstract}
O segundo traço característico é a instituição de uma força pública, que já não mais se identifica com o povo em armas. A necessidade dessa força pública especial deriva da divisão da sociedade em classes, que impossibilita qualquer organização armada espontânea da população [...]. Essa força pública é formada não só de homens armados, como, ainda, de acessórios materiais, os cárceres e as instituições coercitivas de todo gênero, desconhecidos pela sociedade da gens (ENGELS, 2014, p. 209).
\end{abstract}

Evidencia-se assim, que o ponto de partida para discutir sobre a prisão e suas funções é justamente compreendê-la como um dos elementos materiais que compõem a força do Estado. Não obstante, torna-se necessário apropriar-se da concepção de que assim como o próprio Estado - a sua criação deriva da divisão da sociedade em classes.

Desde a sua origem, a prisão expressou um mecanismo fundamental de dominação. No que diz respeito à funcionalidade genérica dessa instituição, Foucault (2014, p. 223) apesar de não se aprofundar em uma análise materialista da prisão - apresenta a análise de que ela surgiu para:

[...] repartir os indivíduos, fixá-los e distribuí-los espacialmente, classificá-los, tirar deles o máximo de tempo e o máximo de forças, treinar seus corpos, codificar seu comportamento contínuo, mantê-los numa visibilidade sem lacuna, formar em torno deles um aparelho completo de observação, registros e notações, construir sobre eles um saber que se acumula e se centraliza. A forma geral de uma aparelhagem para tornar os indivíduos dóceis e úteis, por meio de um trabalho preciso sobre seu corpo, criou a instituição-prisão.

Com base nessa interpretação, verifica-se que a prisão detém um papel fundamental na exploração e dominação de classe e, não poderia ser de outra forma, pois o próprio antagonismo de classes é inerente à origem dessa instituição. Partindo do princípio de que o Estado e seus aparatos coercitivos sempre serão determinados pelo modo de produção, a partir da emergência do capitalismo esse instrumento de dominação e exploração de classe é reconfigurado conforme os interesses da nascente burguesia.

Dessa maneira, a disciplina como política de coerção para produzir sujeitos dóceis e úteis - presente na formulação de Foucault - encontra suas determinações materiais na relação entre capital e trabalho assalariado, configurando-se como adestramento da força 
de trabalho para reproduzir capital, e não como simples investimento do corpo por relações de poder (SANTOS, 2006). Em outras palavras, com o surgimento do sistema de produção capitalista, a prisão descobre suas funcionalidades específicas na pena privativa de liberdade; sistema punitivo compatível com a nascente ordem capitalista.

\section{O Estado Burguês e o Aprisionamento no Capitalismo}

Com base na doutrina marxista sobre o Estado moderno, parte-se aqui da concepção de que esta máquina é um comitê para gerir os negócios comuns de toda a classe burguesa (ENGELS; MARX, 1998). No sistema capitalista de produção o Estado está totalmente submetido à burguesia e suas frações, pois não só o Estado antigo e o Estado feudal eram órgãos de exploração dos escravos e dos servos, como também, "o Estado representativo moderno é um instrumento de exploração do trabalho assalariado pelo capital" (LENIN, 2010, p. 32). Na mesma perspectiva, Engels (2011, p. 90) destaca o seguinte:

O Estado moderno é a organização a que se entrega a sociedade burguesa, para abrigo dos ataques, tanto dos capitalistas individuais como dos operários. O Estado moderno, qualquer que seja a sua forma, é uma máquina essencialmente capitalista, é o Estado dos capitalistas, o capitalista coletivo ideal (ENGELS, 2011, p. 90).

Em outras palavras, o Estado no capitalismo é uma máquina de repressão que permite à classe dominante assegurar a sua dominação sobre os explorados, para submetêlos constantemente ao processo de extorsão da mais-valia, ou seja, à exploração assalariada (ALTHUSSER, 2001).

Como a prisão é parte indispensável da força estatal, o aprisionamento se torna o principal meio punitivo com o advento do sistema capitalista. Essa circunstância comprova a tese de que cada sistema de produção descobre o sistema de punição que corresponde às suas relações produtivas (MELOSSI; PAVARINI, 2010). Entretanto, a imbricação entre capitalismo e prisão passa a se constituir já no período pré-capitalista, visto que:

$\mathrm{Na}$ história da acumulação primitiva, o que faz época são todos os revolucionamentos que servem de alavanca à classe capitalista em formação, mas, acima de tudo, os momentos em que grandes massas humanas são despojadas súbita e violentamente de seus meios de subsistências e lançados no mercado de trabalho como proletários absolutamente livres. A expropriação da terra que antes pertencia ao produtor rural, ao camponês, constituiu a base de todo o processo [...]. A assim chamada acumulação primitiva não é, por conseguinte, mais do que o 
processo histórico de separação entre produtor e meio de produção (MARX, 2013, p. 786; 787).

Esse processo, tão bem analisado por Karl Marx, terminou por criar uma crescente massa de marginalizados que passaram ocupar os centros urbanos, marcando o início do novo modo de produção que estava por se estabelecer. Cézar Henrique Maranhão (2010), na mesma perspectiva, acrescenta que através de um violento combate contra a velha ordem feudal, o capital converteu antigos camponeses e artesãos em homens destituídos de qualquer propriedade, que passaram a possuir somente as suas forças de trabalho, estando disponíveis para serem absorvidos pela indústria moderna.

O aprisionamento, obedecendo aos novos ditames da incipiente ordem econômica - a princípio sem uma função de custódia claramente definida -, já neste contexto, desempenha uma função substancial na manutenção de uma nova classe que se formava, isto é, o proletariado. Isto se explica pelo seguinte motivo:

\begin{abstract}
Expulsos pela dissolução dos séquitos feudais e pela expropriação violenta e intermitente de suas terras, esse proletariado inteiramente livre não podia ser absorvido pela manufatura emergente com a mesma rapidez com que fora trazido ao mundo. Por outro lado, os que foram repentinamente arrancados de seu modo de vida costumeiro tampouco conseguiam se ajustar à disciplina da nova situação. Converteram-se massivamente em mendigos, assaltantes, vagabundos, em parte por predisposição, mas na maioria dos casos por força das circunstâncias. Isso explica o surgimento, em toda a Europa ocidental, no final do século XV e ao longo do século XVI, de uma legislação sanguinária contra a vagabundagem (MARX, 2013, p. 806).
\end{abstract}

Dessa forma, a partir da acumulação primitiva do capital, as penas via suplício corporal deixavam gradativamente de ser o principal meio punitivo na sociedade.

\begin{abstract}
A desproporção das penas, que funcionava, inconscientemente ou não, como agente destruidor da mão-de-obra, começava então a ser colocada em xeque. A questão então volta-se para a construção de políticas que pudessem reduzir toda a força de trabalho desperdiçada e diluída a forma capitalista de subordinação [...]. A intervenção do Estado fez-se então necessária. Os ociosos e vagabundos eram também os que praticavam os pequenos delitos, basicamente contra a propriedade. Neste contexto surge a primeira instituição com o propósito de limpar a cidade de vagabundos e mendigos: o castelo de Bridewell, instituídos em Londres por ordem do rei da Inglaterra. O objetivo da instituição era reformar os internos através do trabalho disciplinado e obrigatório (SERRA, 2009, p. 76).
\end{abstract}

De acordo com a linha argumentativa trilhada pelo autor, é possível perceber que na transição do feudalismo para o capitalismo, a punição via suplício corporal deixa de ser 
aproveitável às novas formas de produção que estavam legitimando-se. Ou seja, era necessário que o Estado desenvolvesse meios punitivos que seriam funcionais à adaptação e à disciplina da exploração assalariada.

Nesse sentido, já no período da acumulação primitiva do capital, o aprisionamento se configura como um dos meios pelo qual o Estado burguês passa a intervir na reprodução e manutenção da força de trabalho. Naquele período, especificamente, o Estado, através do encarceramento, atuava na adaptação à disciplina do trabalho "livre" fabril que estava sendo implementado.

Dessa maneira, com a consolidação do capitalismo como sistema de produção, a criação de um novo método punitivo para combater delitos contra a propriedade passou a ser uma das principais preocupações da burguesia urbana emergente. Onde detivesse o monopólio da legislação e jurisdição, ela insistia nesse ponto com muita força (RUSCHE; KIRCHHEIMER, 2004). Gera-se então o direito penal burguês, afirmando-se como o principal meio jurídico em que se alicerça todo o sistema penal capitalista. Para Evgeni Pachukanis (2017, p. 174),

O direito penal é uma parte integrante da superestrutura jurídica, na medida em que encarna uma modalidade dessa forma fundamental, à qual está subordinada a sociedade moderna: a forma de troca de equivalentes com todas as suas consequências. A realização destas relações de troca, no Direito Penal, constitui um aspecto da realização do Estado de direito como forma ideal das relações entre os produtores de mercadorias independentes e iguais que se encontram no mercado. Porém, como as relações sociais não se limitam às relações jurídicas abstratas, a jurisdição penal não é somente uma encarnação da forma jurídica abstrata, mas também uma arma imediata na luta de classes.

Em outras palavras, o direito penal, ao aplicar à punição a forma de equivalência e de troca - modalidade específica do sistema de produção capitalista - termina por configurar-se como um dos meios pelo qual a classe que detém o poder político-econômico exerça sua dominação. Naves (2008, p. 60) explicita essa questão:

A diferença entre o direito pré-burguês e o direito burguês reside em que só neste se consagra a ideia de que a pena possa estar relacionada com a privação de certa quantidade de tempo. Ora, só em uma sociedade na qual o trabalho humano medido pelo tempo é a forma social dominante, onde, portanto, domina o trabalho abstrato, é que esta ideia pode triunfar. É nesse momento em que surgem as prisões e, não por acaso, a sua constituição se dá sob o modelo da fábrica, ambas sendo postas em funcionamento sob o controle do cronômetro. 
A burguesia, assim, passa a assegurar e manter seu domínio também mediante o sistema de direito penal estatal, comprovando a afirmativa de que "todo determinado sistema histórico de política penal traz as marcas dos interesses da classe que o realizou" (PACHUKANIS, 2017, p. 124).

Não obstante, para compreender melhor de que maneira a prisão legitima-se no sistema capitalista - sobretudo no terreno da força de trabalho -, torna-se necessário considerar alguns aspectos da "lei geral da acumulação capitalista", tese formulada por Marx em "O Capital”. Para ele,

\begin{abstract}
A acumulação capitalista produz constantemente, e na proporção de sua energia e seu volume, uma população trabalhadora adicional relativamente excedente, isto é, excessiva para as necessidades médias de valorização do capital e, portanto, supérflua [...]. Toda a forma de movimento da indústria moderna deriva, portanto, da transformação constante de uma parte da população trabalhadora em mão de obra desempregada ou semiempregada (MARX, 2013, p. 858-861).
\end{abstract}

Em um movimento contraditório, ao integrar a maior quantidade de trabalhadores aptos aos postos de trabalho, o capital produz também, simultaneamente, uma superpopulação relativa, composta por um conjunto de grupos bastante amplos e heterogêneos, abrangendo aqueles trabalhadores que se encontram desempregados ou parcialmente empregados. No entanto, essa superpopulação relativa não é um mero distúrbio do capitalismo que pode ser sanado - como pretendem os ideólogos reformistas -, muito pelo contrário, é algo irreparável, mas necessário e intrínseco à acumulação capitalista. Marx (2013, p. 860) esclarece perfeitamente esse fato:

\footnotetext{
Se uma população trabalhadora excedente é um produto necessário da acumulação ou do desenvolvimento da riqueza com base capitalista, essa superpopulação se converte, em contrapartida, em alavanca da acumulação capitalista, e até mesmo numa condição de existência do modo de produção capitalista. Ela constitui um exército industrial de reserva disponível, que pertence ao capital de maneira tão absoluta como se ele o tivesse criado por sua própria conta. Ela fornece a suas necessidades variáveis de valorização o material humano sempre pronto para ser explorado, independentemente dos limites do verdadeiro aumento populacional.
}

O objetivo exposto aqui ao utilizar a concepção desenvolvida por Marx sobre a "lei geral da acumulação capitalista", é justamente de explicitar a tentativa de apreender a intervenção do Estado burguês na regulação da força de trabalho - tendo como um dos meios o aprisionamento - indissociavelmente da superpopulação relativa, produto 
específico do modo de produção capitalista. A realidade histórica da prisão sob a órbita do capital evidencia que, o alvo principal dessa instituição, vem sendo permanentemente parcelas da superpopulação relativa produzida pela acumulação capitalista.

É importante ressaltar que ao longo do desenvolvimento do capitalismo a superpopulação relativa se apresenta em diversas formas, variando de acordo com as mudanças de fases do ciclo industrial, "fazendo com que ela apareça ora de maneira aguda nas crises, ora de maneira crônica nos períodos de negócios fracos" (MARX, 2013, p. 871). Dessa maneira, a intercessão do Estado pela via do aprisionamento também é determinada de acordo com os distintos momentos vivenciados pelas relações de produção. No período da Revolução Industrial,

[...] a política do Estado trocou de sinal: de responsável pela constituição de um contingente de mão-de-obra capacitada ao emprego na manufatura, para instrumento de terror, mediante o uso sistemático da tortura, da imposição do trabalho inútil, já que a função econômica da prisão, enquanto reguladora do nível de salários, deixara, ainda que temporariamente de existir. [...] Com isso forçava-se o pobre a aceitar o trabalho que the fosse oferecido, quaisquer que fossem as condições. Fora dessa oferta regida pela mão invisível do mercado, apenas duas possibilidades se abriam: a fome ou as casas de trabalho, cujas condições deveriam necessariamente ser inferiores às experimentadas do lado de fora (SERRA, 2009, p. 84).

Como se pode notar, com o desenvolvimento do capitalismo, a prisão assume outra função para além daquela exercida no período em que se deu a acumulação primitiva do capital. Com a mão-de-obra estabilizada, o aprisionamento passa a atuar na repressão implacável àqueles que recusam o trabalho da fábrica e aos crimes (principalmente contra a propriedade privada) cometidos por uma determinada classe, com o objetivo de extinguir toda ameaça à nova ordem burguesa capitalista.

Nessa etapa do capitalismo, com a superpopulação relativa já formada, o pauperismo e a miséria das massas se aprofundam gradativamente e, em consequência, a punição estatal pela via do aprisionamento aumenta de forma considerável. No que se refere a realidade inglesa,

Durante este período o número de condenações cresceu em torno de 540\%. Engels comentou: "A necessidade deixa ao trabalhador a escolha entre morrer de fome lentamente, matar a si próprio rapidamente, ou tomar o que ele precisa onde encontrar - em bom inglês, roubar. E não é motivo para surpresa que muitos dentre eles prefiram o roubo à inanição ou ao suicídio" (ENGELS apud RUSCHE; KIRCHHEIMER, 2004, p. 137). 
A referência que Engels fez à Inglaterra é apenas um exemplo do que ocorreu em diversos países da Europa no final do século XVIII e início do século XIX, isto é, a forte expansão do encarceramento. Sobre este fenômeno, Marco Alexandre Serra (2009) afirma que, ao lado da explosão demográfica, a introdução de máquinas a vapor produziu efeitos catastróficos, pois despejou nas ruas um grande contingente de trabalhadores que foram por elas substituídos. Ainda nessa perspectiva,

O grande número de desempregados e a miséria extrema fazem deste período aquele no qual o salário real desceu aos níveis mais baixos, desde o início do desenvolvimento capitalista. Na realidade, tudo induz à mendicância, ao roubo, e em alguns casos à violência e ao banditismo, a formas primitivas de luta de classe, como os incêndios nos campos, a revolta contra as máquinas e assim por diante (MELOSSI, 2010, p. 93).

Nessa fase, inicia-se ainda, uma constante organização do movimento operário contra as mazelas da exploração, fazendo com que a prisão adquirisse um traço político, intimidador e extremamente coercitivo a qualquer atividade revolucionária. Assim, já no início do desenvolvimento do sistema capitalista e durante todo o período concorrencial, é possível perceber o real caráter imputado à prisão, caráter que, gradualmente, vai legitimando-se no decorrer da história, ou seja, como uma instituição essencialmente política, econômica e classista.

Com o ingresso do capitalismo no estágio imperialista, especificamente com a ascensão dos monopólios, a intervenção estatal muda funcional e estruturalmente. Nas palavras de José Paulo Netto (2011, p. 24),

\footnotetext{
$\mathrm{Na}$ idade do monopólio, ademais da preservação das condições externas da produção capitalista, a intervenção estatal incide na organização e na dinâmica econômicas desde dentro, e de forma contínua e sistemática. Mais exatamente, no capitalismo monopolista, as funções políticas do Estado imbricam-se organicamente com as suas funções econômicas.
}

Entre tais funções do Estado anunciadas pelo autor, inclui-se, principalmente, a reprodução e manutenção da força de trabalho pela via de políticas sociais. Nesse momento - Estado atuará na conservação da força de trabalho, ameaçada pela superexploração capitalista, não mais apenas por meios coercitivos. Verifica-se que na era dos monopólios, esse tipo de intercessão estatal torna-se suportável à dinâmica do capital. De acordo com essa perspectiva, 
[...] O capitalismo monopolista, pelas suas dinâmicas e contradições, cria condições tais que o Estado por ele capturado, ao buscar legitimação política através do jogo democrático, é permeável a demandas das classes subalternas, que podem fazer incidir nele seus interesses e suas reivindicações imediatas. [...] É somente nessas condições que as sequelas da "questão social" tornam-se - mais exatamente: podem tornar-se - o objeto de uma intervenção contínua e sistemática por parte do Estado. E só a partir da concretização das possibilidades econômico-sociais e políticas segregadas na ordem monopólica que a "questão social" se põe como alvo de políticas sociais. [...] Através da política social, o Estado burguês no capitalismo monopolista procura administrar as expressões da "questão social" de forma a atender as demandas da ordem monopólica conformando, pela adesão que recebe de categorias e setores cujas demandas incorpora, sistemas de consenso variáveis, mas operantes (NETTO, 2011, p. 29-30).

Nesse sentido, pode-se compreender que a política social se constitui como um dos meios pelo qual o Estado burguês procura atenuar os antagonismos de classes no capitalismo monopolista. Não obstante, Rosa Luxemburgo (2010) alerta que, se o Estado assume para si funções no âmbito social, é unicamente porque essas funções coincidem momentaneamente com os interesses da classe dominante.

Nos países de capitalismo avançado, o ápice do desenvolvimento da política social é inerente ao período chamado de "anos de ouro", momento em que foi possível uma superficial e passageira conciliação entre acumulação capitalista e "bem-estar social". A gênese da noção do Estado de "bem-estar" está na necessidade de o capitalismo monopolista resistir à tendência de queda da taxa de lucro pela ampliação da mais-valia relativa (LESSA, 2013). Houve então uma espécie de "pacto social" entre a burguesia e algumas frações do movimento operário, que renunciaram ao combate contra a propriedade privada e foram cooptados pelo Estado capitalista, transformando a luta por reformas como fim em si, e não como ponte para a superação do sistema capitalista.

No que diz respeito a esse contexto, o keynesianismo constituiu-se em um dos pilares do processo de acumulação acelerada de capital no pós-1945. Foi esta política que forneceu os fundamentos ideológicos e políticos para o compromisso da "democracia capitalista". Desenvolveu-se a expectativa de que o Estado poderia harmonizar a propriedade privada dos meios de produção com a gestão democrática da economia (PRZEWORSKI; WALLERSTEIN, 1988). Nessa perspectiva, o Estado,

[...] atuou em múltiplos domínios sociais. Os governos desenvolveram programas de formação de mão-de-obra, políticas para a família, planos habitacionais, redes de auxílio pecuniário, sistemas de saúde etc. Tentaram regular a força de trabalho misturando incentivos e impedimentos à participação no mercado de trabalho. 
Procuraram modificar padrões de disparidade racial e regional. [...] A produção cresceu, o desemprego diminuiu, os serviços sociais foram ampliados e reinou a "paz social". Até o final dos anos 60, o keynesianismo foi a ideologia oficial do compromisso de classe, sob a qual diferentes grupos podiam entrar em conflito nos limites de um sistema capitalista e democrático (PRZEWORSKI; WALLERSTEIN, 1988, p. 34).

Como já abordamos, a superpopulação relativa varia de acordo com o momento de desenvolvimento das relações de produção capitalistas; especificamente no período dos "anos de ouro", ela se apresenta de forma oculta. Isto se dá pelo fato de que o Estado burguês, nesse momento, ameniza o exército industrial de reserva ao intervir na reprodução da força de trabalho através de gastos no âmbito social e políticas de pleno emprego. Nesse momento, o que distingue de maneira marcante o papel do Estado - comparado ao estágio concorrencial e ao início da fase monopolista - é "o nível de consciência com o qual este se dedica à gestão da força de trabalho; esta passa a ser a sua função econômica fundamental" (SERRA, 2009, p. 95).

No que se refere ao aprisionamento nesse contexto, percebe-se que:

O poder punitivo é abarcado por toda essa nova estruturação totalizante do
período fordista. Afinal, ele se insere na política integral do Estado. Sua utilização
organizada, isto é, mediante a aplicação de penas, notadamente a prisão, perde um
pouco de importância. Não quer isso dizer, entretanto, que a função repressiva do
Estado tenha sido relegada para um plano secundário. Ainda que de forma mais
latente, ela continua em presença. [...] Nesse contexto, a prisão deve ser percebida
como um capítulo particular mais geral de produção e reprodução da classe
trabalhadora. Isso não conduz à desimportância da função repressiva do Estado,
mas à sua reelaboração estratégica (SERRA, 2009, p. 97).

Todavia, a política de conciliação de classes em que se apoiavam os programas socialdemocratas - e o idealizado "Estado de bem-estar" - passa a demonstrar no final da década de 1960 a sua impossibilidade. Bastou uma nova crise do capital para que se evidenciasse a ruína dos "anos de ouro" nos países de capitalismo avançado. Rompe-se o "pacto de classes" e, consequentemente, o pleno emprego keynesiano e o desenho socialdemocrata das políticas sociais perdem a viabilidade no novo processo de reestruturação capitalista, direcionado pelo programa político-econômico neoliberal.

Neste contexto, as funções do Estado burguês são novamente reconfiguradas. Há uma constante alteração no âmbito das políticas sociais, estas assumem um caráter extremamente assistencialista, focalizado e condicional, demonstrando que, sob a égide do 
destrutivo sistema capitalista, as migalhas destinadas aos explorados se tornam cada vez mais insignificantes e perversas.

Dessa forma, a tese neoliberal de redução do papel do Estado deve ser questionada e relativizada, pois a razão de existência dessa instituição é reafirmada com as diretivas neoliberais. Isto quer dizer que o Estado continua desenvolvendo a sua função essencial: de órgão de dominação e exploração de classe. De maneira geral, o Estado é reduzido em algumas esferas estratégicas, ou seja, privatizando empresas, transferindo serviços públicos para o setor privado, enxugando o quadro administrativo, entre outras.

Para Netto e Braz (2006), a crise do Estado de Bem-Estar nada mais é do que a crise do "capitalismo democrático". Isto é, para estes autores a crise deve ser analisada para além da natureza administrativa; não basta apenas analisá-la como fenômeno exclusivo do caráter financeiro ou tributário, ou como é mais comum, apreender a crise como um simples esgotamento da intervenção social por parte do Estado. Netto (2007, p. 68) esclarece que:

A crise do Welfare State explicita o fracasso do único ordenamento sócio-político que, na ordem do capital, visou expressamente compatibilizar a dinâmica da acumulação e da valorização capitalista com garantia de direitos políticos e sociais mínimos.

Evidencia-se que o "Estado de bem-estar" prevaleceu até o momento em que foi útil e suportável aos interesses do capital. A partir do momento em que o capitalismo entra em mais uma crise estrutural, faz-se necessário um novo modelo político-econômico e a reformatação do Estado. É neste contexto que se constitui a base material para que a ideologia neoliberal fosse colocada em prática.

O constante atrofiamento das políticas sociais e o desmoronamento de direitos conquistados historicamente pela classe trabalhadora em períodos aceitáveis à ordem capitalista, condiciona a ampliação da intervenção punitiva do Estado pela via do aprisionamento. A atenção a esta realidade é fundamental para compreender a interação existente entre política social e encarceramento - a debilidade daquela infere na proliferação deste - no seio da intervenção do Estado burguês, no terreno da regulação da força de trabalho, sobretudo, no âmbito da "superpopulação relativa". Dessa maneira, com a ascensão das políticas de cunho neoliberal, a cíclica alternância de contração e expansão da assistência pública é substituída pela expansão descontrolada do regime prisional (WACQUANT, 2012). 
As forças produtivas nesta etapa do capitalismo vêm gradualmente se decompondo em um processo de estagnação. O estrondoso acúmulo de capital financeiro estrangula a produção nos países avançados e espolia grande parte da riqueza dos países semicoloniais. Nesse sentido,

O desemprego, que antes disso já era estrutural, passa a ser permanente e alcança números inauditos. Parte das parcelas redundantes de trabalho vivo passa a alimentar o mercado de subempregos; os vários nichos do setor terciário, também cada vez mais caracterizados pela precariedade dos direitos, quando não pelo estabelecimento de relações de semi-escravidão ou neosservis (SERRA, 2009, p. 113).

O aprofundamento do desemprego e a constante precarização das condições de trabalho ainda existentes, isto é, a queda de salários, a terceirização de serviços públicos e o caráter assistencialista das políticas sociais destinadas aos explorados - uma das expressões do aspecto internacional da decomposição inevitável do sistema de produção capitalista -, expressam tão somente, o crescente bloqueio das forças produtivas e legitima a miserabilidade de um amplo setor da classe trabalhadora, tanto nos países de capitalismo avançado, quanto nos países semicoloniais.

Dessa maneira, torna-se possível verificar que no capitalismo, em seu contexto neoliberal, a "superpopulação relativa" apresenta-se de forma aguda, reafirmando empiricamente a tese formulada por $\operatorname{Marx}(2013$, p. 719):

\footnotetext{
Mas quanto maior for esse exército de reserva em relação ao exército ativo de trabalhadores, tanto maior será a massa da superpopulação consolidada, cuja miséria está na razão inversa do martírio de seu trabalho. Por fim, quanto maior forem as camadas lazarentas da classe trabalhadora e o exército industrial de reserva, tanto maior será o pauperismo oficial. Essa é a lei geral, absoluta, da acumulação capitalista.
}

O crescente aumento da "superpopulação consolidada", conforme Marx denominou, materializada no exército industrial de reserva, conduz a uma gradual legitimação da penúria das massas mais rebaixadas da classe trabalhadora, expandindo assim o que o autor chamou de "pauperismo oficial". Em tal realidade, a função repressiva do Estado burguês passa a se constituir por duas vias:

Por um lado, um controle mais sub-reptício substituto dos dispositivos disciplinares e dirigido à parcela - bastante reduzida - da força de trabalho útil; de outro, um domínio absoluto que em suma consiste em tirar de circulação os desnecessários à 
realização do valor; a esses últimos, paralela e correspondentemente à reprodução das relações sociais essencialmente desiguais, a prisão deve servir de morada. [...] A função moderna desempenhada pela prisão é bifronte: por um lado escondendo, mediante a criminalização, a miséria; por outro, normalizando o trabalho precário (SERRA, 2009, p. 117-119).

Este fato materializa-se na exacerbação do encarceramento ocorrido nas últimas décadas em diversos países. No Brasil, por exemplo, segundo o Levantamento Nacional de Informações Penitenciárias (INFOPEN), em 1990 a população carcerária era de aproximadamente 90.000 pessoas; em 2015 esse número saltou para 607.731, ou seja, teve um aumento de 575\% em um período de 25 anos (BRASIL, 2014). Nestas circunstâncias, desde a crise do capital iniciada nos países avançados no final da década de 1960, até os dias atuais, nota-se que a prisão assume um papel de destaque no seio da intervenção do Estado burguês.

\section{Considerações finais}

Foi possível verificar no decorrer desta breve análise que a prisão - concebida como um dos elementos materiais que compõem a força do Estado - passa a ser o principal meio punitivo a partir do surgimento do sistema capitalista. Não obstante, assim como o Estado, a prisão vai sendo forjada de acordo com as fases do capitalismo, tendo suas funções reconfiguradas de acordo com os interesses da burguesia.

De um mecanismo de adaptação à exploração assalariada da massa de camponeses expropriados dos meios de produção - período em que se deu a acumulação primitiva do capital - à punição seletiva e classista destinada aos que atentassem contra a propriedade privada - no capitalismo já consolidado -, a prisão hoje constitui-se como depósito de amplos setores da classe trabalhadora empobrecida e mutilada pela barbarização capitalista.

Apesar das mudanças superficiais imputadas ao Estado burguês ocorridas ao longo do desenvolvimento do capitalismo, é possível perceber que o aprisionamento sempre deteve um papel fundamental no seio da intervenção estatal no âmbito da regulação da força de trabalho. Conclui-se que, na contemporaneidade, com o constante atrofiamento das forças produtivas, exacerba-se o pauperismo da superpopulação relativa, fruto da lei geral da acumulação capitalista. Paralelamente, legitima-se o aspecto assistencialista e punitivo do Estado burguês, reconsolidando a prisão como um dispositivo essencialmente 
classista e funcional ao sistema capitalista, forçando o sistema prisional a um estado de barbárie.

\section{Referências}

ALTHUSSER, L. O Estado. In: . Aparelhos Ideológicos de Estado. 8. ed. Rio de Janeiro: Graal, 2001. p. 62-63.

BRASIL. Ministério da Justiça. Departamento Penitenciário Nacional. Levantamento Nacional de Informações Penitenciárias - INFOPEN. Jun. 2014. Disponível em:

$<$ http://www.justica.gov.br/noticias/mj-divulgara-novo-relatorio-do-infopen-nesta-tercafeira/relatorio-depen-versao-web.pdf>. Acesso em: 20 mar. 2016.

ENGELS, Friedrich. A formação do Estado entre os germanos. In: . A origem da família, da propriedade privada e do estado. Rio de Janeiro: BestBolso, 2014, p. 177-220. . Do socialismo utópico ao socialismo científico. 2. Ed. São Paulo: Edipro, 2011. ; MARX, K. Manifesto comunista. São Paulo: Boitempo, 1998.

FOUCAULT, M. Vigiar e punir: nascimento da prisão. 42. Ed. Petrópolis: Vozes, 2014.

LENIN, V. I. Classes sociais e o estado. In: O estado e a revolução: o que ensina o marxismo sobre o Estado e o papel do proletariado na revolução. 2. ed. São Paulo: Expressão Popular, 2010. p. 25-41.

LESSA, S. O que é, mesmo, o estado de bem-estar? In . Capital e estado de bem-estar: o caráter de classe das políticas públicas. São Paulo: Instituto Lukács, 2013. p. 175-219.

LUXEMBURGO, R. Política alfandegária e militarismo. In . Reforma ou Revolução? 2. ed. São Paulo: Expressão Popular, 2010. p. 51-58.

MARX, K. A assim chamada acumulação primitiva. In: . O capital: crítica da economia política. São Paulo: Boitempo, 2013. Livro I: O processo de produção do capital, p. 785-833. . A Lei geral da acumulação capitalista. In: O capital: crítica da economia política.. São Paulo: Boitempo, 2013. Livro I: O processo de produção do capital, p. 835-958. O 18 de Brumário de Luís Bonaparte. São Paulo: Boitempo, 2011.

MELOSSI, D.; PAVARINI, M. Cárcere e fábrica: as origens do sistema penitenciário (séculos XVI - XIX). 2. ed. Rio de Janeiro: Editora Revan, 2010.

NAVES, M. B. Circulação e forma jurídica. In: Marxismo e direito: um estudo sobre Pachukanis. São Paulo: Boitempo, 2008, p. 53-78. 
NETTO, J. P. As condições histórico-sociais da emergência do Serviço Social. In:

Capitalismo monopolista e serviço social. 8. ed. São Paulo: Cortez, 2011. p. 19-69.

. Crise do socialismo e ofensiva neoliberal. 4.ed. São Paulo: Cortez, 2007.

; BRAZ, M. O capitalismo contemporâneo. In: NETTO, J. P.; BRAZ, M. Economia

Política. São Paulo: Cortez, 2006. Cap. 9, p. 211-241.

PACHUKANIS, E. B. Teoria geral do direito e marxismo. São Paulo: Boitempo, 2017.

PRZEWORSKI, A.; WALLERSTEIN, M. O capitalismo democrático na encruzilhada. Novos Estudos, São Paulo, n. 22, out 1988. Disponível

em:<http://novosestudos.org.br/v1/files/uploads/contents/56/20080623_o_capitalismo_de mocratico.pdf>. Acesso em: 15 jan. 2017.

RUSCHE, G.; KIRCHHEIMER, O. Punição e estrutura social. 2. ed. Rio de Janeiro: Revan, 2004.

SANTOS, J. C.. Prefácio à edição brasileira. In: MELOSSI, D.; PAVARINI, M. Cárcere e fábrica: as origens do sistema penitenciário (séculos XVI - XIX). 2. ed. Rio de Janeiro: Revan, 2010. p. $5-9$.

SERRA, M. A. S. Economia política da pena. Rio de Janeiro: Revan, 2009.

WACQUANT, L. Forjando o estado neoliberal: trabalho social, regime prisional e insegurança social. In: BATISTA, V. M. (Org). Loïc Wacquant e a questão penal no capitalismo neoliberal. Rio de Janeiro: Revan, 201. p. 11-42. 
Recebido em: 03/08/2017 Aceito em: 08/01/2018 